\title{
Managing Nile perch using slot size: is it possible? ${ }^{\star}$
}

\author{
M. Nuiru ${ }^{1 *}$, A. Getabu ${ }^{2}$, A.M. TaAbu ${ }^{3}$, E. Mlaponi ${ }^{4}$, L. Muhoozi ${ }^{3}$ and O.C. Mkumbo ${ }^{5}$ \\ ${ }^{1}$ Moi University, Department of Fisheries and Aquatic Sciences, P.O. Box 1125, Eldoret, Kenya \\ ${ }^{2}$ Kenya Marine and Fisheries Research Institute, P.O. Box 1881, Kisumu, Kenya \\ ${ }^{3}$ National Fisheries Resources Research Institute, P.O. Box 343, Jinja, Uganda \\ ${ }^{4}$ Tanzania Fisheries Research Institute, P.O. Box 475, Mwanza, Tanzania \\ ${ }^{5}$ Lake Victoria Fisheries Organisation, P.O. Box 1625, Jinja, Uganda \\ *Corresponding author: rmnjiru2002@yahoo.com
}

\begin{abstract}
The fishery of Lake Victoria became a major commercial fishery with the introduction of Nile perch in 1950s and 1960s. Biological and population characteristics point to a fishery under intense fishing pressure attributed to increased capacity and use of illegal fishing gears. Studies conducted between 1998 to 2000 suggested capture of fish between slot size of 50 to $85 \mathrm{~cm}$ TL to sustain the fishery. Samples from Kenya and Uganda factories in 2008 showed that $50 \%$ and $71 \%$ of individuals processed were below the slot size respectively. This study revealed that fish below and above the slot has continued being caught and processed. This confirms that the slot size is hardly adhered to by both the fishers and the processors. The paper explores why the slot size has not been a successful tool in management of Nile perch and suggests strategies to sustain the fishery.
\end{abstract}

Key words: Lake Victoria, Nile perch, exploitation, management, slot size.

\section{Introduction}

The Nile perch, Lates niloticus (L.), is a predatory fish highly valued in both commercial and recreational fisheries which can grow to $2 \mathrm{~m}$ in length and weigh over $200 \mathrm{~kg}$ (Ogutu-Ohwayo, 2004). It is widely distributed in Africa, occurring in the Congo, Niger, Volta and Senegal Rivers, and in Lakes Chad and Turkana, and throughout the Nile system as far as Lake Albert but was prevented from reaching Lake Victoria by the Murchison Falls. It was introduced into Lake Victoria from Lake Albert during the 1950's and early 1960's (Pringle, 2005) in order to convert the small and bony but abundant haplochromine cichlids to suitable table fish (Anderson, 1961). Opponents of the introduction feared that Nile perch might deplete the stocks of native fish species as well as its own numbers, through cannibalism, which would cause the fisheries to collapse (Fryer, 1960). It took about two decades for Nile perch to establish itself in the lake but its numbers increased rapidly in the late 1970s, leading to a dramatic increase in fisheries productivity (Ogutu-Ohwayo, 1990). At the same time, predation by Nile perch brought about a reduction in the

`Paper presented to the Lake Victoria
Stakeholder's Conference, Kampala,
27-30 October 2008

numbers of many native species with haplochromines falling from $>80 \%$ of the biomass during the 1970's to $<1 \%$ by the mid- 1980 's, and it was feared that many species had become extinct (Ogutu-Ohwayo, 1990; Njiru et al., 2008).

The growth of the fishery and increasing fishing intensity led to a decline in catches of Nile perch creating fears that the fishery might not be sustainable without appropriate management measures (Matsuishi et al., 2006; Njiru et al., 2007). Studies carried out between 1998 and 2000 suggested that the capture of fish between 50 and 85 $\mathrm{cm}$ TL could be permitted and slot sizes of 50 to $85 \mathrm{~cm}$ TL were gazetted by the countries around the lake with enforcement starting in mid-2000s. This paper examines the extent to which fishermen and the processing factories adhere to the slot sizes, using information collected at landing beaches, processing factories, as well as published and unpublished literature. Factors that could have led to the decline in Nile perch in Lake Victoria are discussed and possible management strategies suggested.

\section{Genesis of the slot size}

Catches

Annual catches of Nile perch in Lake Victoria increased from $30,000 \mathrm{t}$ in the late $1970 \mathrm{~s}$ to a peak of $560,000 \mathrm{t}$ in 1999. In Kenya, for example, the Nile perch catch increased 
from $146 \mathrm{t}$ in 1973 to $115,000 \mathrm{t}$ in 1999 but then declined to $30,000 \mathrm{t}$ in 2007 (Figure 1). The Ugandan catch increased from $11,000 \mathrm{t}$ in 1977 to $120,000 \mathrm{t}$ in the early $1990 \mathrm{~s}$ but fragmentary data from the $1990 \mathrm{~s}$ makes it difficult to determine trends, except that by 2000 the catch was around $175,000 \mathrm{t}$. In Tanzania, the catch increased from 72,000 $\mathrm{t}$ in 1983 to $231,000 \mathrm{t}$ in 1990 but the poor catch assessment data in that country means that trends cannot be identified (Matsuishi et al., 2006; Njiru et al., 2007). Recent data suggest that the monthly catches of Nile perch have not declined significantly over the short term, except in Kenya (Figure 2) where the total catch fell from 290,000 $t$ in 2005 to $260,000 \mathrm{t}$ in 2006 and 230,000 $\mathrm{t}$ in 2007 (Lake Victoria Fisheries Organization, unpublished data).

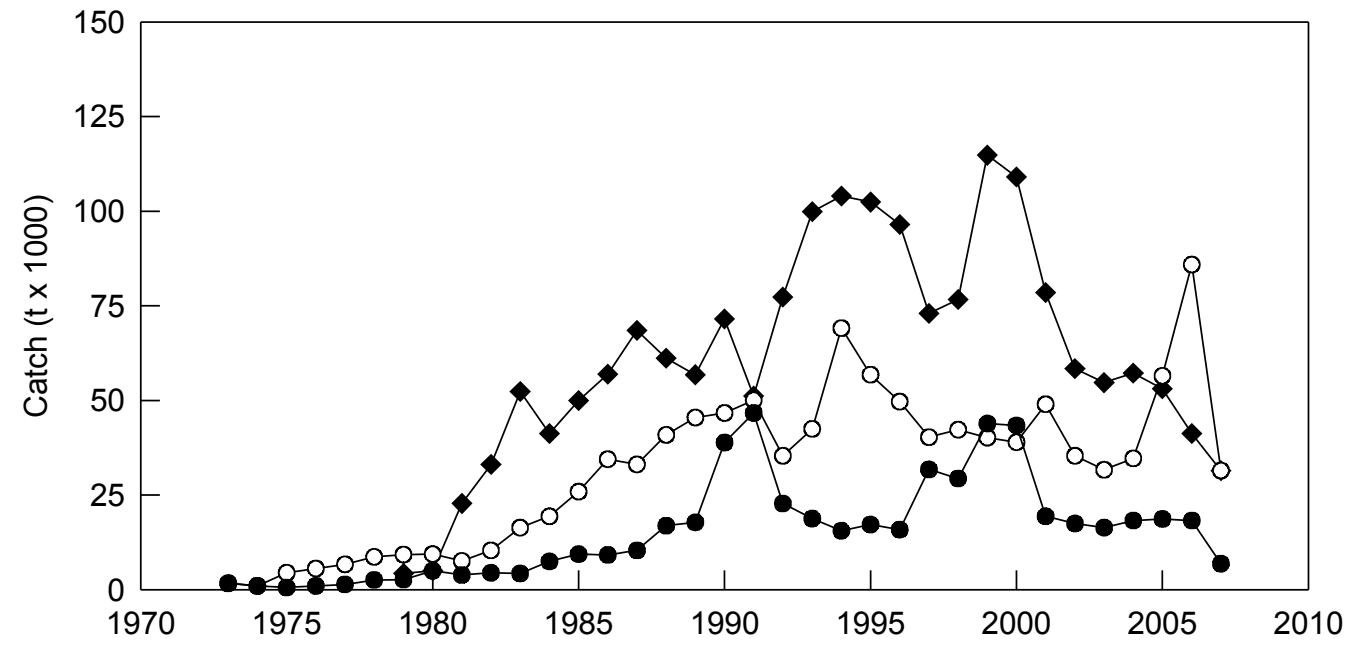

Figure 1. Fish catches from the Kenyan sector of Lake Victoria, 1973-2007. $\downarrow=$ Lates niloticus, $\bigcirc=$ Rastrineobola argentea, $\mathbf{O}=$ tilapias (mostly Oreochromis niloticus). Source: unpublished data from Kenya Marine and Fisheries Research Institute, Kisumu.

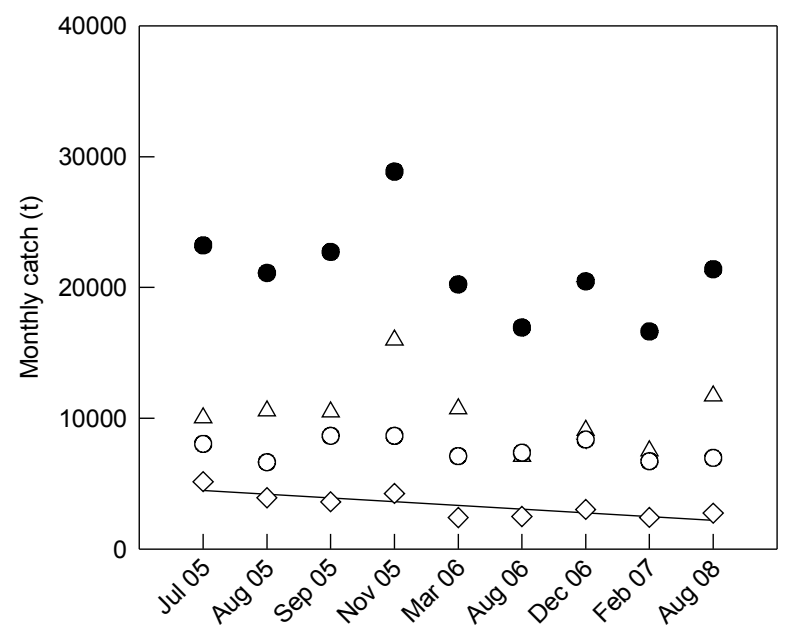

Figure 2. Estimated monthly catches of Nile perch in Lake Victoria, 2005-2008. - total catch, $\diamond=$ Kenyan catch, $\triangle$ $=$ Tanzanian catch, $\bigcirc=$ Ugandan catch. The only significant trend was for the Kenyan catch $(y=4465.5$ 284.6x $, r=0.810, p<0.01)$. Source: LVFO unpublished data.

\section{Population and biological characteristics}

The slot size is based on the premise that Nile perch $\leq 50$ $\mathrm{cm}$ TL feed predominantly on the shrimp Caridina nilotica (Roux), thus converting invertebrates into fish flesh while larger fish are predominantly piscivorous, feeding mainly on the cyprinid Rastrineobola argentea (Pellegrin), juvenile Nile perch, Nile tilapia, Oreochromis niloticus (L.) and haplochromines (Figure 3), which is both destructive to the lake's biodiversity and energetically wasteful. Harvesting Nile perch $\geq 50 \mathrm{~cm}$ TL could also lead to the recovery of the haplochromines, thus enhancing the productivity of the fisheries, especially in deep waters where only the pelagic $R$. argentea occurs at present. Female Nile perch grow to a larger size and mature later than males and up to 2006 males and females reached 50\% maturity at 54-64 and $62-85 \mathrm{~cm}$ TL respectively (Table 1). The sex ratio changed with size because males were smaller than females and most fish $>80 \mathrm{~cm}$ were females (Hughes, 1992) but the removal of large fish by the fishery has resulted in a more or less equal sex ratio in the 40-60 size class (LVFO, unpublished data). Thus, the slot size of 50 to $85 \mathrm{~cm} \mathrm{TL}$ sought to protect immature fish, harvest mature individuals and at the same time protect the larger females which would be expected to replenish the stocks. 


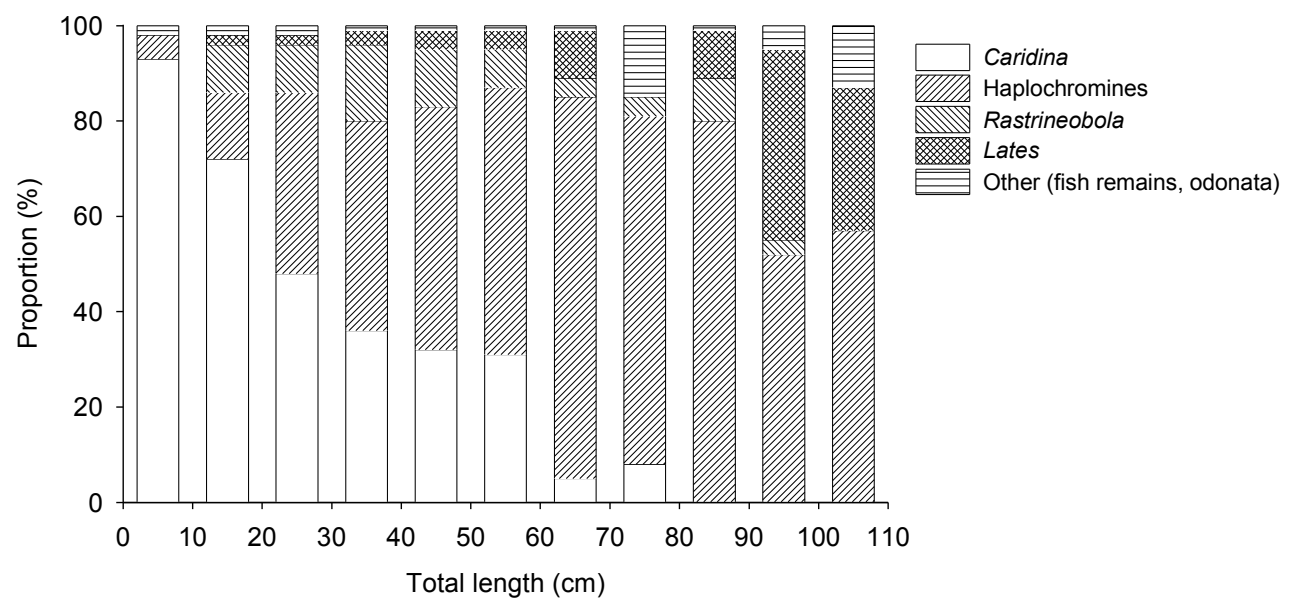

Figure 3. The prey eaten by Lates niloticus in relation to size in Lake Victoria, Tanzania, from 1997 to 2001 (adapted from Mkumbo, 2002).

Table 1. Changes in the length at $50 \%$ maturity $(\mathrm{cm} \mathrm{TL})$ in male and female Nile perch from Lake Victoria. Adapted from Njiru et al. $(2007,2008)$

\begin{tabular}{lcrc}
\hline \multicolumn{1}{c}{ Area } & Year & $\begin{array}{c}\mathrm{L}_{\mathrm{m} 50} \\
\text { (males) }\end{array}$ & $\begin{array}{c}\mathrm{L}_{\mathrm{m} 50} \\
\text { (females) }\end{array}$ \\
\hline Kenya & 1988 & 74 & 102 \\
& 2002 & 55 & 78 \\
& 2006 & 55 & 62 \\
\hline Tanzania & 1985 & 54 & 68 \\
& 2002 & 64 & 73 \\
& 2003 & 57 & 76 \\
& 2006 & 58 & 70 \\
\hline Uganda & 1990 & 60 & 110 \\
& 2002 & 54 & 77 \\
& 2006 & 60 & 85 \\
\hline
\end{tabular}

\section{Factors that may be hindering the effectiveness of the slot size}

Factories and markets

The continued capture of immature Nile perch may be a consequence of the increased demand for fish. The number of factories processing Nile perch increased from 32 in 2000 to 35 in 2005 before falling to 27 in 2008 (Table 2 ) and their capacity exceeds the quantity of fish they are able to obtain (SEDAWOG, 1999; Abila, 2000). The factories once processed Nile perch with a minimum weight of 2 to $3 \mathrm{~kg}$ but as a result of increased competition for fish and the reduced numbers of large ones they now accept smaller fish, sometimes only weighing $1 \mathrm{~kg}$. Some export markets prefer fillets from $0.5-\mathrm{kg}$ fish (or smaller) owing to their low fat content while the local and regional markets accept fish of any size (Muhoozi, 2002). This market demand has encouraged use of small gillnets $(<127 \mathrm{~mm}$ mesh), beach seines and small hooks which target small
Nile perch. A recent survey showed that most Nile perch landed at beaches were below the length at first maturity $\left(\mathrm{Lm}_{50}\right)$ while most fish sent to the factories and filleted were also below the slot size (Figure 4).

Table 2. Changes in the number of Nile perch processing factories around Lake Victoria (LVFO, unpublished data).

\begin{tabular}{lccc}
\hline & 2000 & 2005 & 2008 \\
\hline Kenya & 11 & 6 & 6 \\
Tanzania & 9 & 17 & 10 \\
Uganda & 9 & 12 & 11 \\
\hline Total & 31 & 35 & 27 \\
\hline
\end{tabular}

\section{Ownership}

Fish processing factories control the Nile perch fishing industry and have marginalized local fishers because there is intense competition for fish to meet the demand of the processing plants (SEDAWOG, 1999). The prominent fishers also compete to harvest more, factories to buy more than a nearby factory or in another country. The fish processing factories or prominent fishers can register any number of canoes without limit, and pay a fishing license $(\approx$ \$US 5 per boat) while there is no limit to the numbers of nets being used as long as the vessel can carry them. There is no system of ensuring that fishers use legal gear apart from what is reported during registration. The factory processors have an association where they strategise and dictate terms in the industry, whereas fishers do not have such a forum and are therefore unable to take a common stand. Fishers are totally at the mercy of the fish processing factories and with the loss of control to "foreign investors", local fishers have been deprived of ownership, which traditionally has been in the community (Geheb and Crean 2000), leading them to resort to irresponsible fishing practices (Yongo et al., 2005). 


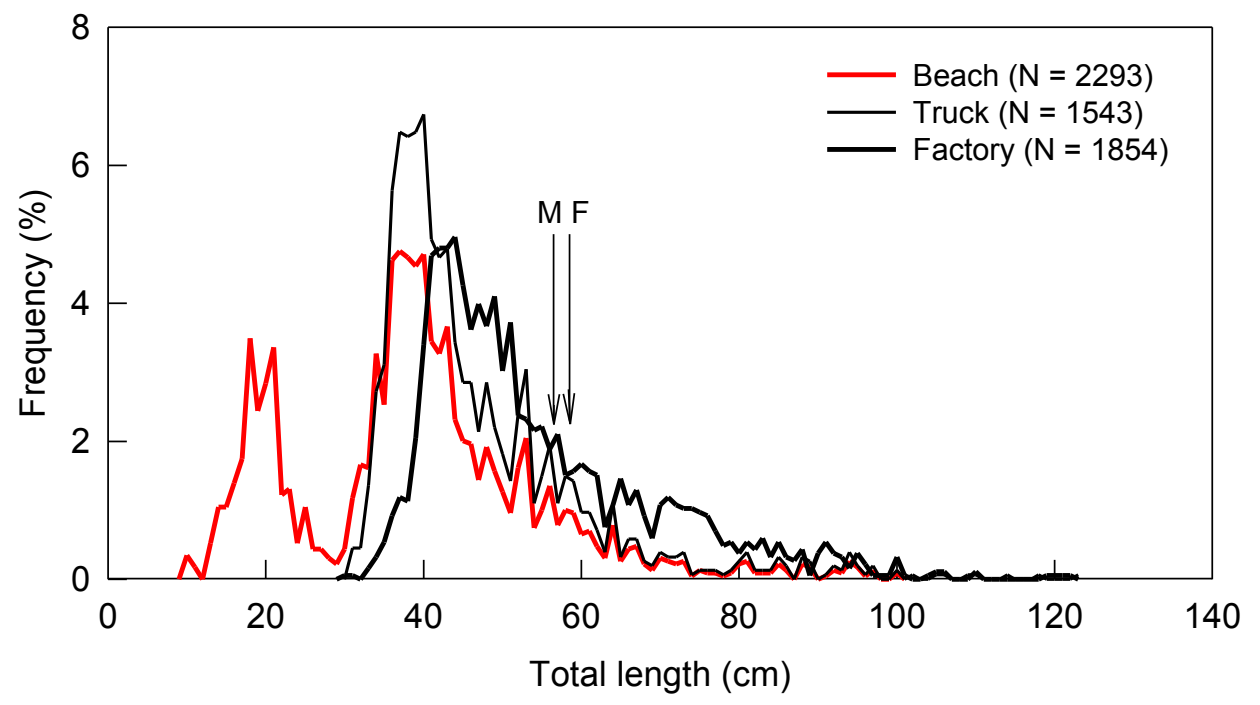

Figure 4. Length frequency distribution of Nile perch landed in beaches, loaded in trucks and in fish processing factories in Kenya in September 2007. The lines marked M and F denotes the length at first maturity of males $(56.5 \mathrm{~cm})$ and females

$(58.5 \mathrm{~cm})$, respectively (data from LVFO, 2007a).

\section{Open access}

The Lake Victoria fishery is an open-access without any limitation on the total number of fishers, boats and gears used. The demand for fish from Lake Victoria has continued to increase over the years (Abila, 2000) and so fishing effort has also increased (Cowx et al., 2003; Njiru et al., 2008). Fishers are using more efficient illegal fishing gears and methods to get more fish irrespective of their sizes (Cowx et al., 2003). The recommended gill mesh size for the lake fishery is 5 inches $(127 \mathrm{~mm})$, but gill nets $<5$ inches are still prevalent while banned gears such as beach seines, cast nets and monofilaments are still being used (Njiru et al., 2008) and when used in shallow areas all of them capture immature Nile perch.

The declining catch per unit effort (CPUE) has made fishing with legal fishing gears unprofitable without costly investments such as larger boats, outboard motors, or large quantities of gillnets (Muhoozi, 2002). The majority of fishers in lake cannot afford such investments and consequently resort to illegal fishing practices such as joining small-meshed gillnets ( $<5$ inches) together so a fleet of 80 nominal nets in one canoe is actually 240 nets, which may extend spread up to $3 \mathrm{~km}$ and are drifted by boats with outboard engines. This fishing method is more efficient but is also a source of conflict between fishers because it destroys passively set nets (SEDAWOG, 1999; Muhoozi, 2002). Although, the active operation of gillnets is illegal in Uganda $85 \%$ of boats fishing in the inshore areas operated gillnets actively (Muhoozi, 2002). These fishing methods probably enable fishers to maintain reasonably high catches of Nile perch, many of them undersized, at a time when the stocks are declining.
Security

Theft of gears and piracy has become a problem on Lake Victoria and has influenced the way fishers conduct their fishing activities (SEDAWOG, 1999). In addition, the high cost of the legal fishing gears has led to the use illegal fishing gears and methods (Muhoozi, 2002) such as cast nets and beach seines which are less easily stolen as they are under the control of fishers at all times. It has been argued that the Kenyan part of the lake is highly productive because it is shallow, has numerous river mouths and high nutrient loads, and is therefore the major breeding and nursery area of Nile perch and so fishing should be restricted to deeper waters (Njiru et al., 2007). This has led to conflicts with Kenyan fishers being imprisoned in Uganda and Tanzania in pursuit of "their adult fish" but this view is unverified and it will remain so until investigations into fish migration have been carried out. Fishers who do not venture into the deeper waters of the lake and run the risk of being detained remain in the shallow waters where they target juvenile perch with illegal fishing methods.

\section{Fishing for Rastrineobola and Caridina}

The decline of Nile perch stocks in Lake Victoria, has led a shift towards the more abundant Rastrineobola which could have some adverse effects on the Nile perch stock because of its mode of fishing. Fishing for Rastrineobola is supposed to be carried out in deeper waters during dark nights by light attraction using $10-\mathrm{mm}$ mesh nets. This is not the case in shallow areas $<5 \mathrm{~m}$ deep, where fishing goes throughout the year without light attraction and with 5-mm mesh nets (Muhoozi, 2002). Fishers sometimes join several of these nets vertically and horizontally so that they are up 
to $500 \mathrm{~m}$ in length. They are then used as beach seines, and this method is unselective, capturing juvenile fish of all species and so endangering recruitment.

The shrimp Caridina is harvested for poultry meal production in Nairobi and Dar es Salaam, and as it is the most important prey item for smaller Nile perch (Figure 2) this could result in a scarcity of food for fish $<60 \mathrm{~cm} \mathrm{TL}$ (Budeba, 2003). This might eventually have an adverse effect on the Nile perch stock but, despite the importance of Caridina little is known about its ecology in Lake Victoria. In Tanzania, Caridina is neglected during recording of catches (Budeba, 2003) and there is a need for more information on this fishery.

\section{Policies and enforcement}

Policies and regulations governing Lake Victoria's resources which are different in each country (Ntiba et al., 2001), but substantial efforts towards harmonisation have been made by the Lake Victoria Fisheries Organisation (LVFO, 2007b). For, example, the use of monofilaments was banned in Tanzania and Kenya and allowed in Uganda, but during the LVFO Council of Ministers Session in February 2009, a joint communiqué was signed to ban monofilament in the three Partner States. The same session set the minimum mesh size for $R$. argentea at $10 \mathrm{~mm}$ instead of $5 \mathrm{~mm}$ nets. However, fishing for $R$. argentea is prohibited only in Kenya between 1 April and 31 August. Where some regulations are similar, the penalties are different. There is therefore an urgent need to harmonise all the regulations and penalties in the Lake Victoria fishery and treat the lake as one system.

\section{Management strategies}

Capacity and enforcement

The Nile perch population is dominated by small individuals $(<40 \mathrm{~cm}$ TL) which suggests successful recruitment (Figure 4). These small fish occur mostly in water $<10 \mathrm{~m}$ deep which appears to be the most heavily fished area (Ligtvoet et al., 1995; Njiru et al,. 2008). Illegal fishing gears and methods in the shallow zones of the lake can lead to growth over-fishing resulting in depletion of the stock as few mature individuals are given a chance to replenishment it (Mkumbo, 2002). To sustain the fishery, the recommended slot sizes should be enforced, entry into the fishery should be limited through licensing, and illegal fishing gears and methods eradicated.

\section{Funding}

Lake Victoria's fisheries generate up to US $\$ 500$ million annually mostly from Nile perch export (Yongo et al., 2005) but no substantial funds are ploughed back for research and management. Instead, fishery management agencies rely heavily on donor funds and donors whose objectives might not be of immediate concern to management of the lake. Consequently, there is a need to source money locally, perhaps from taxes levied on the fishing industry to support research and management needed to maintain the fishery resources. In such a situation, research would have to be demand-driven and aim to answer specific issues raised by stakeholders.

\section{Alternative livelihoods}

Even with the best management systems in place, the supply of fish from the lake will be insufficient to meet the ever growing demand (Abila, 2000; Yongo et al., 2005) because with a population growing at 3\% the demand for fish outstrips the catch. Aquaculture, which is poorly developed around Lake Victoria, could be a viable option but much needs to be done since the combined production from. Kenya, Uganda and Tanzania is less than $10000 \mathrm{t}(<$ $0.02 \%$ of global production) (Mushi et al., 2005). The contribution from aquaculture should be greater because East Africa region has an adequate year-round photoperiod, extensive water bodies and wetlands, and suitable native species aquaculture suitable for fish farming Development of aquaculture, and other activities like ecotourism or horticulture might reduce pressure on the Victoria fisheries provided they could provide adequate livelihoods to a sufficiently large number of people.

\section{Co-management}

Properly implemented monitoring, control and surveillance schemes should be linked to community-based management approaches because government enforcement has been successful up to now (Ntiba et al., 2002). The study by SEDAWOG (1999) found that beach communities formed for patrol and monitoring of their fishing grounds to deter thieves and control illegal gears were very effective. Since Beach Management units (BMUs), of which all fishermen must be members, have been established to coordinate fishing activities at all landing beaches around the lake. Co-management will transfer responsibilities and privileges to the stakeholders giving them a sense of ownership of the resource and if this approach succeeds illegal gears and the capture of undersized fish will be much reduced or, hopefully, eliminated. Security is a major problem but this could be strengthened by integrating communities into the management of the fishery resource through the BMUs, but their success will depend on local commitment the one hand and strong political support on the other.

\section{References}

Abila, R. (2000). The development of the Lake Victoria fishery: A boom or bane for food security? IUCN, Nairobi, Kenya. No. 8: 28 pp.

Anderson, A.M. (1961). Further observations concerning the proposed introduction of Nile perch into Lake Victoria. East African Agricultural and Forestry Journal 26: 195-201.

Budeba, Y. (2003). The role of Caridina nilotica (Roux 1833 ) in the Lake Victoria fisheries, Tanzanian waters. $\mathrm{PhD}$, thesis, Hull University, UK.

Cowx, I.G., M. van der Knaap, L.I. Muhoozi and A. Othina (2003). Improving fishery catch statstics for Lake Victoria. Aquatic Ecosystem Health and Management 6: 
299- 310.

Fryer, G. (1960). Concerning the proposed introduction of Nile perch into Lake Victoria. East African Agriculture Journal 25: 267-270.

Geheb, K. and K, Crean, eds (2000). The co-management survey: co-managerial perspectives for Lake Victoria's fisheries. Lake Victoria Fisheries Research Project Technical Document 11: 183 pp. Lake Victoria Fisheries Research Project, Jinja, Uganda.

Hughes, N.F. (1992). Growth and reproduction of the Nile perch, Lates niloticus, an introduced predator, in the Nyanza Gulf, Lake Victoria, East Africa. Environmental Biology of Fishes 33: 299-305.

Kaufman, L. (1992). Catastrophic change in species rich freshwater ecosystem: lessons of Lake Victoria. Bioscience 42: 846-858.

Kolding, J., P. van Zwieten, O. Mkumbo, G. Silsbe and R. Hecky (2008). Are the Lake Victoria fisheries threatened by exploitation or eutrophication? Towards an ecosystem-based approach to management. In: G. Bianchi and H.R. Skjoldal (eds). The Ecosystem Approach to Fisheries. FAO, Rome and CABI International, Wallingford, UK, pp. 309-354.

Ligtvoet, W., P.J. Mous, O.C. Mkumbo, Y.L. Budeba, P.C. Goudswaard, E.F.B. Katunzi, M.M. Temu, J.H. Wanink and F. Witte (1995). The Lake Victoria fish stocks and fisheries. In: F. Witte and W.L.T. van Densen (eds). Fish Stocks and Fisheries of Lake Victoria. A Handbook for Field Observations. Samara Publishing, Cardigan, UK, pp. 11-53.

Lung'ayia, H.B.O., A. M'Harzi, M. Tackx, J. Gichuki and J.J. Symoens (2000). Phytoplankton community structure and environment in the Kenyan waters of Lake Victoria. Freshwater Biology 43: 529-543.

LVFO (2007a). Report of the fish factory sampling exercise: length at first maturity of Nile perch in Lake Victoria. Implementation of a Fisheries Management Plan. Lake Victoria Fisheries Research Organisation, Jinja, Uganda: 6 pp.

LVFO (2007b). LVFO Regional Plan of Action for the Management of the Fishing Capacity in Lake Victoria. Lake Victoria Fisheries Research Organisation, Jinja, Uganda: $28 \mathrm{p}$.

Matsuishi, T., L. Muhoozi, O. Mkumbo, Y. Budeba, M. Njiru, A. Asila, A.Othina and I.G. Cowx (2006). Are the exploitation pressures on the Nile perch fisheries resources of Lake Victoria a cause for concern? Fisheries Management and Ecology 13: 53-71.

Mugidde, R., J. Gichuki, D. Rutagemwa, L. Ndawula and A. Matovu (2005). Status of water quality and implications on fishery production. In: The state of the fisheries Resources of Lake Victoria and their Management. Proceedings of the Regional Stakeholder's Conference 24-25 February 2005, Entebbe, Uganda. Lake Victoria Fisheries Organization, Jinja, Uganda, pp 106-112.

Muhoozi, L.I. (2002). Exploitation and management of the artisanal fisheries in the Ugandan waters of Lake
Victoria. PhD Thesis. University of Hull, Hull, UK.

Mkumbo, O.C. (2002). Assessment and management of Nile perch (Lates niloticus L.) stocks in the Tanzanian waters of Lake Victoria. PhD, thesis, Hull University, UK.

Mushi, V.E., D.N. Oenga and W.W. Mwanja (2005). Meeting increasing demand for fish through development of aquaculture in the Lake Victoria Basin. In: The State of the Fisheries Resources of Lake Victoria and their Management. Proceedings of the Regional Stakeholder's Conference 24-25 February 2005, Entebbe, Uganda. Lake Victoria Fisheries Organisation, Jinja, Uganda, pp. 159-165.

Njiru M, J. Kazungu, C.C. Ngugi, J. Gichuki and L. Muhoozi (2008). An overview of the current status of Lake Victoria fishery: opportunities, challenges and management strategies. Lakes and Reservoirs: Research and Management 13: 1-12.

Njiru, M., P. Nzungi, A. Getabu, E. Wakwabi, A. Othina, T. Jembe and S. Wekesa (2007). Are fisheries management measures successful in Lake Victoria, Kenya? The case of Nile perch and Nile tilapia Fishery. African Journal of Ecology 45: 315-323.

Ntiba, M.J., W.M. Kudoja and C.T. Mukasa (2001). Management issues in the Lake Victoria watershed. Lakes and Reservoirs: Research and Management 6 : 211-216.

Ochumba, P.B.O. (1990). Massive fish kills within the Nyanza Gulf of Lake Victoria, Kenya. Hydrobiologia 208: 93-99.

Ogutu-Ohwayo, R. (1990). The decline of the native fishes of Lakes Victoria and Kyoga (East Africa) and the impact of introduced species, especially the Nile perch, Lates niloticus and the Nile tilapia, Oreochromis niloticus. Environmental Biology of Fishes 27: 81-96.

Ogutu-Ohwayo, R. (2004). Management of the Nile perch, Lates niloticus fishery in Lake Victoria in light of the changes in its life history. African Journal of Ecology 42: 306-314.

Pringle, R.M. (2005). The origins of the Nile perch in Lake Victoria. BioScience 55: 780-787.

SEDAWOG (1999). The survey of Lake Victoria's fishers. Socio-ecoomic Working Group, Technical Document No 5: 37 pp. Lake Victoria Fisheries Research Project, Jinja, Uganda.

Scheren, P.A.G.M., H.A. Zanting and A.M.C. Lemmens (2000). Estimation of water pollution sources in Lake Victoria, East Africa: application and elaboration of the rapid assessment methodology. Journal of Environmental Management 58: 235-248.

Yongo, E., B.B. Keizire and H.G. Mbilinyi (2005). Socioeconomic impacts of fish trade. In: The State of the Fisheries Resources of Lake Victoria and their Management. Proceedings of the Regional Stakeholder's Conference 24-25 February 2005, Entebbe, Uganda. Lake Victoria Fisheries Organization, Jinja, Uganda, pp 132-142. 